\title{
Canine leishmaniosis in South America Filipe Dantas-Torres*
}

Address: Department of Veterinary Public Health, Faculty of Veterinary Medicine, University of Bari, 70010 Valenzano, Bari, Italy Email: Filipe Dantas-Torres* - filipe.vet@globo.com

* Corresponding author

from 4th International Canine Vector-Borne Disease Symposium Seville, Spain. 26-28 March 2009

Published: 26 March 2009

Parasites \& Vectors 2009, 2(SuppI I):SI doi: I0.I I86/I756-3305-2-SI-SI

This article is available from: http://www.parasitesandvectors.com/content/2/SI/SI

(C) 2009 Dantas-Torres; licensee BioMed Central Ltd.

This is an Open Access article distributed under the terms of the Creative Commons Attribution License (http://creativecommons.org/licenses/by/2.0), which permits unrestricted use, distribution, and reproduction in any medium, provided the original work is properly cited.

\begin{abstract}
Canine leishmaniosis is widespread in South America, where a number of Leishmania species have been isolated or molecularly characterised from dogs. Most cases of canine leishmaniosis are caused by Leishmania infantum (syn. Leishmania chagasi) and Leishmania braziliensis. The only wellestablished vector of Leishmania parasites to dogs in South America is Lutzomyia longipalpis, the main vector of $L$. infantum, but many other phlebotomine sandfly species might be involved. For quite some time, canine leishmaniosis has been regarded as a rural disease, but nowadays it is wellestablished in large urbanised areas. Serological investigations reveal that the prevalence of antiLeishmania antibodies in dogs might reach more than $50 \%$, being as high as $75 \%$ in highly endemic foci. Many aspects related to the epidemiology of canine leishmaniosis (e.g., factors increasing the risk disease development) in some South American countries other than Brazil are poorly understood and should be further studied. A better understanding of the epidemiology of canine leishmaniosis in South America would be helpful to design sustainable control and prevention strategies against Leishmania infection in both dogs and humans.
\end{abstract}

\section{Background}

South America is a large continent located in the western hemisphere. Most of its landmass is situated within the tropical zone (which extends from the equator to the north and south parallels of $23^{\circ} 30^{\prime}$ ), which provides a very suitable environment for many kinds of arthropods (e.g., ticks, mosquitoes and phlebotomine sandflies) that can act as vectors of a number of pathogens. As a corollary, people living in South America are exposed to a number of arthropod-borne diseases, including malaria, leishmaniosis and dengue fever. Similarly, dogs are also affected by many arthropod-borne diseases, including ehrlichiosis, babesiosis, dirofilariosis and leishmaniosis $[1,2]$.

Canine leishmaniosis is widespread in South America and it is among the most important canine vector-borne diseases occurring in this region, mainly because of its major zoonotic relevance [1-4]. The present article provides an overview on key aspects related to canine leishmaniosis in South America, emphasising future research needs. 
Table I - Leishmania species infecting dogs in South America.

\begin{tabular}{llll}
\hline Species & Disease form & Suspected/proven vectors a & Geographical distribution \\
\hline $\begin{array}{ll}\text { L. amazonensis } \\
\text { L. braziliensis }\end{array}$ & Visceral & Unknown & Brazil \\
L. colombiensis & Cutaneous & Lu. whitmani, among others & Argentina, Bolivia, Brazil, Colombia, Peru, Venezuela \\
L. infantum & Visceral & Unknown & Venezuela \\
& Visceral & Lu. longipalpis, Lu. evansi, Lu. youngi, & Argentina, Bolivia, Brazil, Colombia, French Guiana ${ }^{b}$, \\
L. mexicana & Cutaneous & among others & Venezuela \\
L. panamensis & Cutaneous & Lu. trapidoi & Couador \\
L. peruviana & Cutaneous & Lu. peruensis, Lu. verrucarum & Colombia, Ecuador \\
L. pifanoi & Cutaneous & Unknown & Peru \\
\hline
\end{tabular}

a Lutzomyia spp. that have been suspected to be involved in the transmission of Leishmania spp. to dogs in South America. Further information on the phlebotomine sand flies have been implicated as vectors of Leishmania spp. in this region can be found elsewhere [15,23].

${ }^{b}$ Autochthonous transmission in French Guiana is uncertain (see text for details).

\section{Leishmania species infecting dogs in South America}

A number of Leishmania species have been isolated or molecularly characterised from dogs in South America (Table 1). They include Leishmania amazonensis, Leishmania braziliensis, Leishmania colombiensis, Leishmania infantum (syn. Leishmania chagasi), Leishmania mexicana, Leishmania panamensis, Leishmania peruviana, and Leishmania pifanoi [5-12]. With the exception of L. amazonensis, which has not been isolated from dogs so far, the other species have been isolated and characterised by traditional methods (e.g., isoenzyme electrophoresis) [5-11]. In the cases of canine leishmaniosis by L. amazonensis reported in São Paulo, south-eastern Brazil, the species identification was performed by using a Leishmania-specific rDNA-based PCR assay on lymph node samples, followed by hybridisation with a L. amazonensis-specific probe [12].

Leishmania infantum is the most important causative agent of canine visceral leishmaniosis in South America. Dogs have been regarded as the main reservoir hosts of L. infantum, which is a parasite of major zoonotic concern, particularly in Brazil where 3500 cases of human visceral leishmaniosis are reported annually; about $10 \%$ of the cases have resulted in a fatal outcome [13]. Dogs infected by $L$. infantum can develop a life-threatening disease characterised by lymphadenomegaly, muscular atrophy, skin ulceration, weight loss and onychogryphosis (Figure 1). It is a common concept that all dogs with visceral leishmaniosis in South America are infected by $L$. infantum. However, in Venezuela, a strain characterised by isoenzyme analysis as L. colombiensis was isolated from a dog presenting visceral leishmaniosis [7]. In Brazil, two dogs diagnosed as having visceral leishmaniosis were actually infected by L. amazonensis [12]. These reports highlight the importance of using proper diagnostic tools

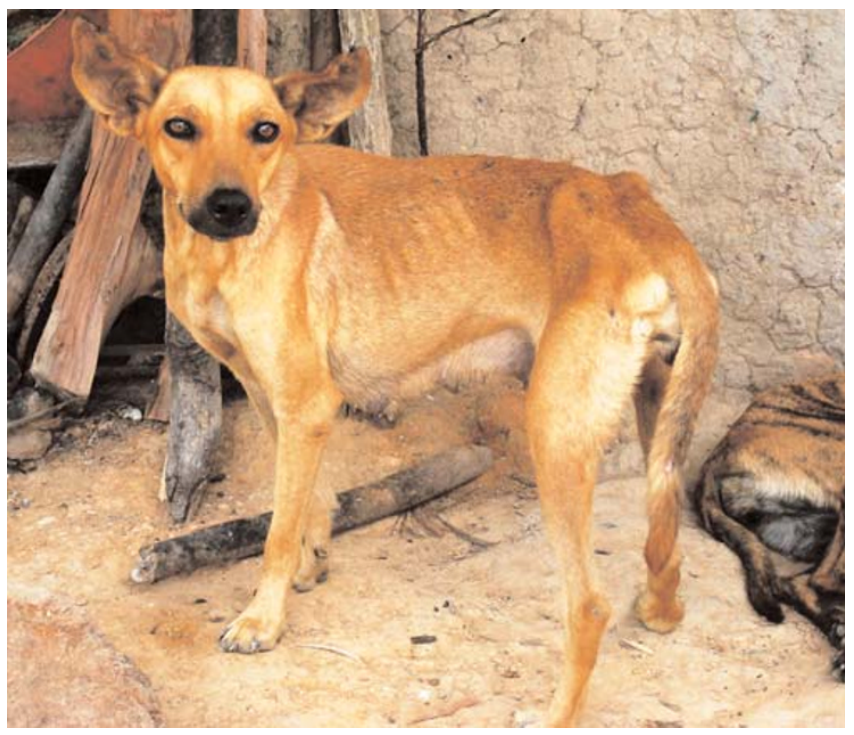

Figure I - Canine visceral leishmaniosis.

A Leishmania-seropositive dog showing facial muscular atrophy, skin lesions, loss of weight, and onychogryphosis.

to identify the species of Leishmania involved in each case of canine leishmaniosis irrespective of the clinical form.

Leishmania braziliensis is the main causative agent of cutaneous leishmaniosis in dogs in South America [10]. Most of the dogs infected by L. braziliensis live in rural areas and they may present single cutaneous or mucosal lesions (Figure 2) [14]. Dogs have been suspected to play a role in the domestic transmission cycle of $L$. braziliensis and $L$. peruviana in some areas of South America, but there is only circumstantial evidence supporting this hypothesis [10]. In 


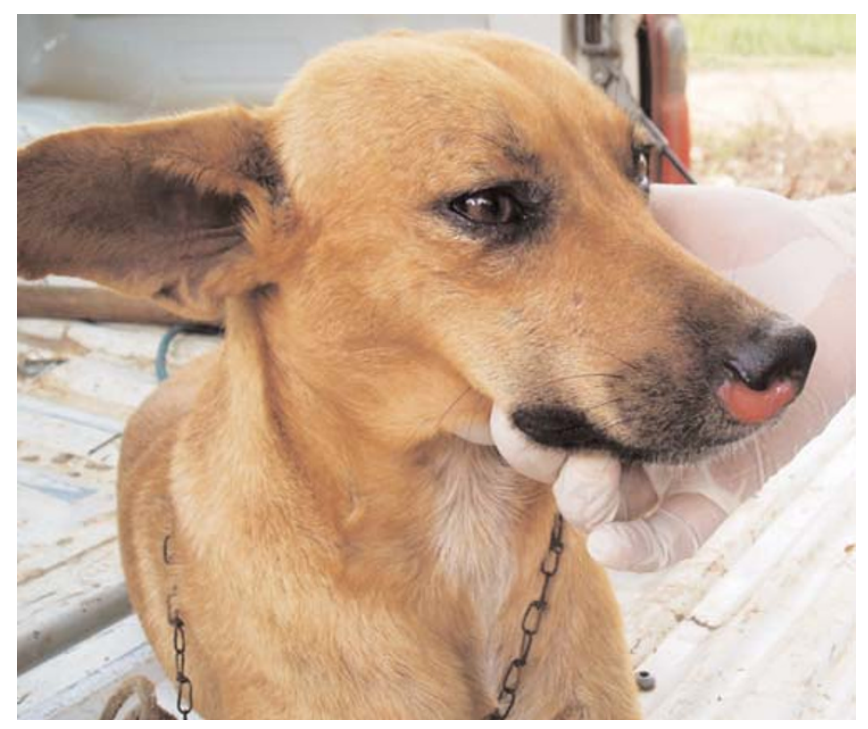

Figure 2 - Canine cutaneous leishmaniosis.

A Leishmania-seropositive dog presenting a mucocutaneous lesion on nose.

fact, the role of dogs in the maintenance of these parasites is probably minor [3].

Hybrid Leishmania strains have also been isolated from dogs in South America. For example, L. braziliensis/ L. peruviana and L. braziliensis/L. guyanensis hybrid strains have been isolated from dogs in Peru and Venezuela, respectively [10]. The hybrid strains have phenotypic and genotypic features of two Leishmania species, and it has been suggested that these hybrids might represent strains that originated directly from a common ancestor or that they might be the result of genetic exchange [15].

In certain areas, the enzootic transmission cycles of different Leishmania parasites might overlap and dogs might become co-infected. For instance, cases of coinfection by $L$. infantum and L. braziliensis in dogs have been reported in south-eastern Brazil $[16,17]$. Coinfection by $L$. infantum and other trypanosomatids (e.g., Trypanosoma evansi) in dogs have also been reported [18]. For instance, a new species of Trypanosoma (namely Trypanosoma caninum) has recently been isolated from a dog co-infected with L. braziliensis in south-eastern Brazil [19]. Co-infections might be relevant in terms of diagnosis because of the possibility of serological crossreactions among different Leishmania species [20] and with other related trypanosomatids $[19,21]$.

\section{Transmission of Leishmania parasites to dogs}

The primary mode of transmission of Leishmania parasites from dog to dog is through the bite of an infected phlebotomine sandfly. In South America, the vectors of

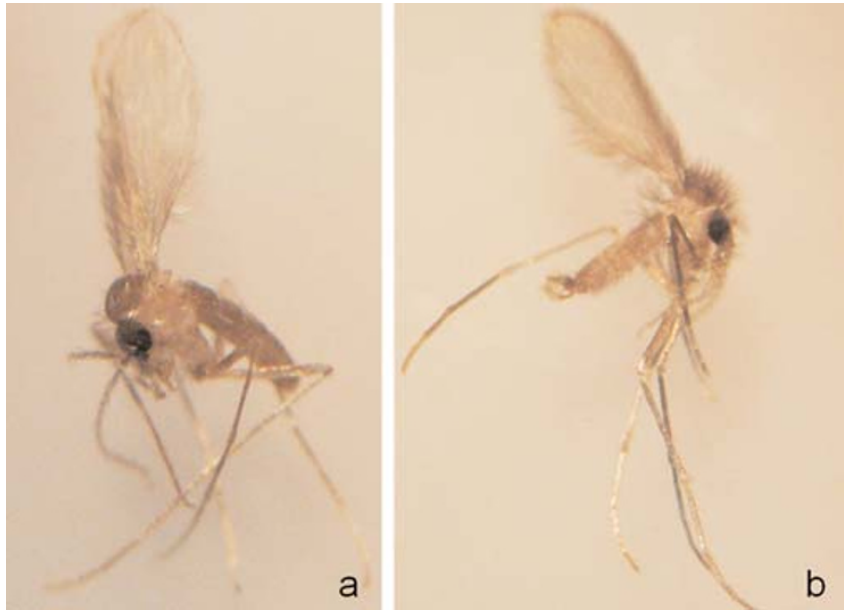

Figure 3 - Lutzomyia sand flies.

A female (a) and a male (b) of Lutzomyia migonei, a putative vector of $L$. infantum in some regions of Brazil [24,32].

Leishmania parasites belong to the genus Lutzomyia (Figure 3). Over 70 species of Lutzomyia have been suspected to be implicated in the transmission of the eight Leishmania species known to infect dogs in South America [15,22-29]. However, the only well-established vector of Leishmania parasites to dogs in South America is Lutzomyia longipalpis [24]. This phlebotomine sandfly is a proven vector of $L$. infantum, widespread in South America [23], and has an opportunist feeding behaviour. However, it is interesting to note that in some areas dogs are not the preferred source of blood of Lu. longipalpis. For instance, in a recent study carried out in central-western Brazil, it was found that $\mathrm{Lu}$. longipalpis fed preferentially on birds, rodents, humans, opossums, oxen, horses and dogs, in decreasing order of importance [30]. In these areas, the role of dogs as reservoir hosts of L. infantum could be of minor relevance.

Molecular biology techniques, in particular PCR-based tools, have impacted many fields of parasitology, including the study of a number of parasites and their respective arthropod vectors. The development of PCRbased tools for the detection of Leishmania DNA in phlebotomine sandflies has increased the number of putative vectors of Leishmania parasites in South America, see, for example, [25-29]. However, the detection of Leishmania DNA in a given Lutzomyia species, the mere detection per se, does not necessarily mean vector competence. In fact, experimental transmission studies are needed to prove the role of a given phlebotomine sandfly species as a vector of Leishmania parasites, even though these studies might be expensive, time-consuming and require considerable expertise on phlebotomine sandfly rearing. 
The absence of $L u$. longipalpis in some areas where cases of canine leishmaniosis have been reported [31,32] has suggested the participation of other phlebotomine sandfly species or the existence of secondary modes of transmission. Secondary modes of transmission that have been suggested in the literature include transplacental transmission [33], via blood transfusion [34], and venereal transmission $[31,35]$. However, the relevance of alternative ways of transmission is unknown. In a similar way, fleas and ticks have long been regarded as putative vectors of $L$. infantum in Brazil [36-39], but an overwhelming proof that they are competent vectors of Leishmania parasites has never been provided.

\section{Geographical distribution}

Canine leishmaniosis is a widespread disease in South America (Figure 4). Infection by Leishmania parasites in dogs have been reported in all countries except Chile, Uruguay, Suriname, and Guyana (see Table 1). Cases of canine visceral leishmaniosis by L. infantum (zymodeme MON-1) have been diagnosed in French Guiana, although autochthonous transmission has not yet been demonstrated [31].

Leishmania braziliensis and $L$. infantum are the most widespread species infecting dogs in South America and their distribution is probably wider than it is actually conceived. In recent years, there has been a southward spreading of canine leishmaniosis caused by L. infantum in South America. For example, the disease has recently been diagnosed in previously free areas of southern Brazil [40] and northern Argentina [41].

For a long time, canine leishmaniosis was considered to be a disease confined to rural areas. Nowadays, the disease is well-established in large urbanised areas such as the metropolitan region of Belo Horizonte, south-eastern Brazil [42]. Many factors could favour the spreading of canine leishmaniosis in South America, including the movement of dogs between endemic and non-endemic areas [31] and changes in vector ecology. Lutzomyia longipalpis is widespread in South America [23] and it is adapted to colonise environments modified by man [24]. In the State of Pernambuco, north-eastern Brazil, sparse spots of modified Atlantic rainforest can be found in highly urbanised areas. These remnants of Atlantic rainforest are potentially inhabited by phlebotomine sandflies of many species [43], including Lu. longipalpis [44]. It means that the introduction of a Leishmaniainfected dog into a non-endemic area where the potential vectors are present could result in the establishment of a new focus of disease. In fact, if the current tendency continues [40,41], new foci of the disease should be expected to be detected in the future.

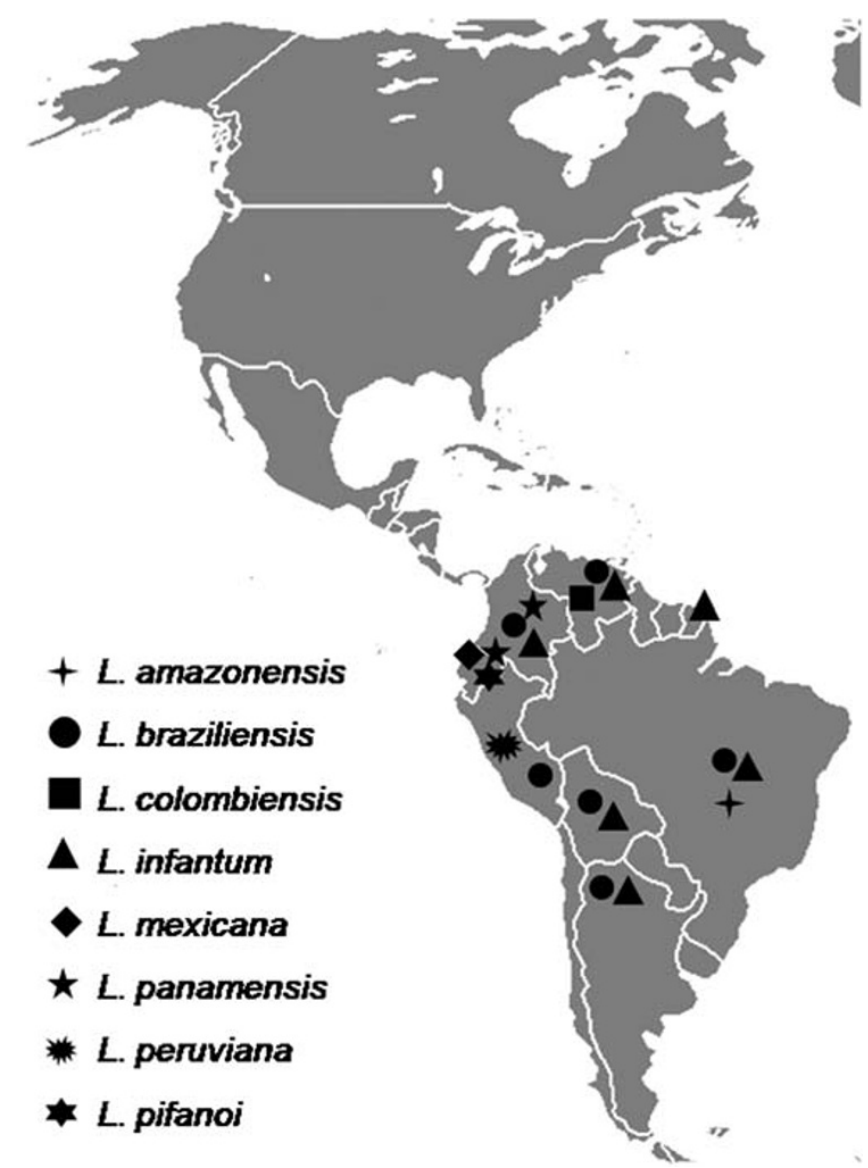

Figure 4 - Distribution of Leishmania spp. infecting dogs in South America.

The distribution of some species is probably wider than currently known. For instance, L. braziliensis and L. infantum are endemic in Paraguay [15], but there are no published reports of infection in dogs.

\section{Prevalence of infection}

Most information on the prevalence of infection among dogs came from serological surveys conducted in Brazil, see, for example [45-48], and at a much lesser extent in other countries such as Argentina [49], Colombia [50] and Venezuela [51]. Although the prevalence of Leishmania spp. infection in dogs in South America can vary widely from region to region, and according to the diagnostic method used, it is usually over $25 \%$ $[21,47,49,51,52]$ and might be as high as $75 \%$ in highly endemic foci [53]. However, it is difficult to estimate the overall prevalence of Leishmania infection in dogs in South America because of the limited amount of published data from some countries (e.g., Paraguay), the existence of methodological differences among studies (e.g., sample size and criteria of positivity) and the inherent limitations of serology (e.g., possibility of cross reactions). 




Figure 5 - Dog's lifestyle can increase the risk of Leishmania infection.

This picture shows a free-roaming dog (black arrow), an animal shelter (white arrow), a spot of modified Atlantic rainforest (black arrowhead), and an area of deforestation (white arrowhead) for agriculture. In this rural area, dogs are highly exposed to sand flies, which can be found inside houses, in animal shelters and forested areas.

An important epidemiological feature that has been observed in South America (and also in the Mediterranean basin) [54] is that the majority of the dogs infected by L. infantum are apparently healthy, exhibiting no visible clinical signs of visceral leishmaniosis. In some foci in Brazil, over $80 \%$ of the seropositive dogs might be clinically healthy $[47,55]$. This information might be relevant because seropositive but apparently healthy dogs can also serve as a source of infection to phlebotomine sandflies [56,57].

\section{Risk factors associated with infection and disease}

Studies attempting to assess the risk factors associated to infection in dogs in South America have been conducted mainly in Brazil. In some areas, there is a higher prevalence of anti-Leishmania antibodies among males when compared with females [47], but in others there has been no association between gender and seropositivity [48]. In some areas, there is a higher seroprevalence in young dogs (< 1 year) [47], whereas in other areas older dogs (1-6 years) are at a higher risk of infection [48]. This apparent disagreement among studies might reflect the local nature of canine leishmaniosis. The epidemiology of the disease varies widely among different regions and risk factors associated to infection in different disease foci might be difficult to predict. One important risk factor is the dog's lifestyle. For instance, guard dogs that are kept outside houses during the whole night are more exposed to sandfly bites and therefore are at a higher risk of

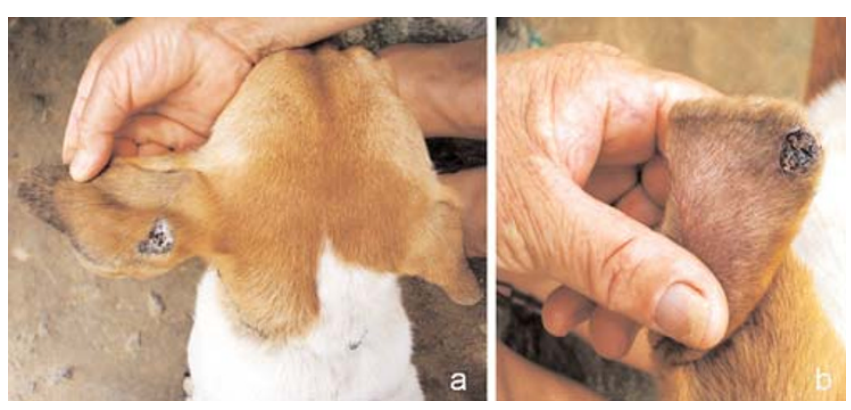

Figure 6 - Skin lesions in a Leishmania-seropositive dog.

Skin lesions on the ears of a dog, the same indicated in Figure 5, which was positive for anti-Leishmania antibodies.

These lesions were possibly caused by L. braziliensis, which is highly prevalent in this area (municipality of Amaraji,

Pernambuco, north-eastern Brazil) [59].

infection as compared with companion dogs that are kept inside houses $[48,58]$. In some rural areas, dogs (Figures 5 and 6) are highly exposed to phlebotomine sandflies, which can be found inside houses, in animal shelters and forested areas [59].

The risk factors underlying the outcome of infection by Leishmania parasites in dogs in South America are poorly understood. The majority of the dogs living in rural and suburban areas are mongrel dogs [47] and the susceptibility to L. infantum infection in these dogs has been shown to be associated with MHC class II polymorphism [60]. The relationship between nutritional status (which is a known risk factor for human visceral leishmaniosis) and the susceptibility to L. infantum infection in dogs should be further investigated.

\section{Control of canine leishmaniosis in South America Vector control}

Vector control is probably the most effective way to prevent Leishmania infection. For instance, a study conducted in Brazil has shown that deltamethrin-impregnated collars have potent anti-feeding and insecticidal effects on $L u$. longipalpis and Lutzomyia migonei [61] and could reduce the risk of infection in dogs. The impact of this strategy within a community is dependent on collar coverage (i.e., number of dogs using the collar within a community) and loss rate [62]. In reality, the use of deltamethrin-impregnated collars is not very popular among dog owners living in rural and suburban areas, probably because of their costs. Usually, the poor social and economic conditions of many dog owners living in rural and suburban areas in South America do not allow them to afford even basic needs of life. Perhaps, a systematic control of phlebotomine sandflies in these areas, by using deltamethrin-impregnated collars or 
other strategies (e.g., spot-on combination of permethrin and imidacloprid) [63] could be possible, if supported by local public health authorities.

\section{Culling of seropositive dogs}

While not universally accepted, the culling of seropositive dogs has long been recommended in Brazil [64]. However, in addition to be ethically arguable, the culling of seropositive dogs has had limited impact on the incidence of human visceral leishmaniosis. From 1990 to 1994, more than 80,000 dogs were culled in Brazil and during the same period there was an increase of almost $100 \%$ in the incidence of human visceral leishmaniosis [4]. The possible reasons (e.g., replacement of the culled dogs for susceptive puppies, low sensitivity and specificity of serological tests used to screen dogs to be culled, owners' unwillingness to cull their seropositive dogs) for the failure of this strategy have been extensively discussed in recent years [64-66]. One important feature that counts against this strategy is the fact that many culled dogs are not actually infected by L. infantum. In Rio de Janeiro (southeastern Brazil), for example, a parasitological study of 66 dogs positive for anti-Leishmania antibodies revealed that 12 dogs were infected only by L. braziliensis [17]. In areas where both $L$. infantum and L. braziliensis are endemic, the use of contemporary techniques to identify the species involved in each case is imperative to avoid the culling of seropositive dogs that are actually infected by L. braziliensis.

\section{Vaccination}

Until recently, there were no commercially available vaccines against canine leishmaniosis. Two vaccines have been licensed for use in Brazil. The first vaccine (Leishmune ${ }^{\circledast}$, Fort Dodge Animal Health) consists of a Leishmania donovani glycoprotein fraction and presents $76-80 \%$ of efficacy [67]. The second vaccine (Leish-Tec ${ }^{\circledR}$, Hertape Calier Saúde Animal) [68] consists of adenovirus expressing a L. donovani A2 antigen, but the results from phase-III trials have not been published yet. These vaccines are expected to become more and more popular among veterinarians and dog owners. Perhaps, the vaccination of dogs in association with a systematic vector control could replace the indiscriminate culling of seropositive dogs in endemic areas.

\section{Final considerations and research needs}

Canine leishmaniosis is widespread in rural and urban areas in South America, although the factors associated with risk to Leishmania infection in dogs from this region are still poorly understood. Dogs are exposed to infection by a number of Leishmania species, which are potentially transmitted by different Lutzomyia species. Moreover, secondary modes of transmission might be involved and could be relevant for the establishment of new foci of canine leishmaniosis in non-endemic areas. Overall, this illustrates how complex is the epidemiology of canine leishmaniosis in South America and highlights the future research needs.

Little is known about the genetic relationship among the Leishmania parasites isolated from dogs, Lutzomyia sandflies and humans in many areas where canine leishmaniosis is endemic in South America. In this context, new attempts to isolate and characterise the species of Leishmania parasites circulating among dogs from urban and rural areas in different South American countries should be encouraged.

Despite of the long list of putative vectors, the only wellestablished vector of Leishmania parasites to dogs in South America is Lu. longipalpis. Indeed, dogs can serve as a source of Leishmania infection to different Lutzomyia species (e.g., Lutzomyia whitmani, Lutzomyia evansi and Lutzomyia youngi) [69-71]. However, it has yet to be proved that these Lutzomyia species are able to transmit the infection to a susceptible dog during a subsequent blood feeding.

In the same way, it is important to investigate the factors associated with risk to Leishmania infection in dogs, keeping in mind that these concepts cannot be generally extrapolated because canine leishmaniosis is a focal disease, whose epidemiology may vary widely from region to region. Some aspects (e.g., poor nutrition) might increase the risk of disease development, but so far this relationship has not been fully addressed in South American dogs. The factors dictating which dog will become sick (and when it will do so) should be addressed in future studies.

For some time, researchers working in South America have focused most of their efforts on canine leishmaniosis by L. infantum and L. braziliensis. Despite the inarguable importance of these two parasites, the study of canine leishmaniosis caused by other Leishmania species (e.g., L. amazonensis and L. colombiensis) would deserve more attention in the future. This constitutes a neglected issue that could provide new insights into the knowledge of the natural history of Leishmania parasites and the diseases they cause.

\section{Competing interests}

The author declares that they have no competing interests.

\section{Acknowledgements}

I would like to express my sincere thanks to Professor Domenico Otranto and Dr. Luciana A. Figueredo for their valuable comments on a draft of the manuscript.

This article is published as part of Parasites \& Vectors Volume 2 Supplement I, 2009: Proceedings of the 4th International Canine Vector-Borne Disease 
Symposium. The full contents of the supplement are available online at http://www.parasitesandvectors.com/supplements/2/SI.

Publication of the supplement has been sponsored by Bayer Animal Health $\mathrm{GmbH}$.

\section{References}

I. Dantas-Torres F: Canine vector-borne diseases in Brazil. Parasit Vectors 2008, I:25.

2. Otranto D, Dantas-Torres F, Breitschwerdt EB: Managing canine vector-borne diseases of zoonotic concern: part one. Trends Parasitol, in press.

3. Dantas-Torres F: The role of dogs as reservoirs of Leishmania parasites, with emphasis on Leishmania (Leishmania) infantum and Leishmania (Viannia) braziliensis. Vet Parasitol 2007, | 49:|39-| 46.

4. Dietze R, Barros GB, Teixeira L, Harris J, Michelson K, Falqueto A, Corey R: Effect of eliminating seropositive canines on the transmission of visceral leishmaniasis in Brazil. Clin Infect Dis | 997, 25: I240-1242.

5. Mayrink W, Williams P, Coelho MV, Dias M, Martins AV, Magalhães PA, da Costa CA, Falcão AR, Melo MN, Falcão AL: Epidemiology of dermal leishmaniasis in the Rio Doce Valley, State of Minas Gerais, Brazil. Ann Trop Med Parasitol 1979, 73:123-137.

6. Hashiguchi Y, Gomez EA, de Coronel VV, Mimori T, Kawabata M, Furuya M, Nonaka S, Takaoka H, Alexander JB, Quizhpe AM, et al.: Andean leishmaniasis in Ecuador caused by infection with Leishmania mexicana and L. major-like parasites. Am J Trop Med Hyg I99I, 44:205-2I7.

7. Delgado O, Castes M, White AC Jr, Kreutzer RD: Leishmania colombiensis in Venezuela. Am JTrop Med Hyg 1993, 48: I45- I 47.

8. Dereure J, Espinel I, Barrera C, Guerrini F, Martini A, Echeverria R, Guderian RH, Le Pont F: Leishmaniose en Equateur. 4. Infestation naturelle du chien par Leishmania panamensis. Ann Soc Belg Med Trop 1994, 74:29-33.

9. Llanos-Cuentas EA, Roncal N,Villaseca P, Paz L, Ogusuku E, Pérez JE, Cáceres A, Davies CR: Natural infections of Leishmania peruviana in animals in the Peruvian Andes. Trans $R$ Soc Trop Med Hyg 1999, 93:15-20.

10. Reithinger R, Davies CR: Is the domestic dog (Canis familiaris) a reservoir host of American cutaneous leishmaniasis? A critical review of the current evidence. Am J Trop Med Hyg 1999, 61:530-54I.

II. Zerpa O, Pratlong F, Ulrich M, Convit J: Isolation of Leishmania infantum, zymodeme MON-I from canine and human visceral leishmaniasis on Margarita Island, Venezuela. Mem Inst Oswaldo Cruz 200I, 96:90I-902.

12. Tolezano JE, Uliana SR, Taniguchi HH, Araújo MF, Barbosa JA, Barbosa JE, Floeter-Winter LM, Shaw JJ: The first records of Leishmania (Leishmania) amazonensis in dogs (Canis familiaris) diagnosed clinically as having canine visceral leishmaniasis from Araçatuba County, São Paulo State, Brazil. Vet Parasitol 2007, 1 49:280-284.

13. Dantas-Torres F: Increasing case-fatality rate of visceral leishmaniasis in Brazil. REVISA 2005, I:260-263.

14. Madeira MF, Schubach AO, Schubach TM, Serra CM, Pereira SA, Figueiredo FB, Confort EM, Quintella LP, Marzochi MC: Is Leishmania (Viannia) braziliensis preferentially restricted to the cutaneous lesions of naturally infected dogs? Parasitol Res 2005, 97:73-76.

15. Lainson R, Shaw J]: New World leishmaniasis. In Topley \& Wilson's Microbiology and Microbial Infections, Parasitology. Edited by Cox FEG, Kreier JP, Wakelin D. London: Arnold; 2005:3 3 3-349.

16. Madeira MF, Schubach AO, Schubach TM, Pacheco RS, Oliveira FS, Pereira SA, Figueiredo FB, Baptista C, Marzochi MC: Mixed infection with Leishmania (Viannia) braziliensis and Leishmania (Leishmania) chagasi in a naturally infected dog from Rio de Janeiro, Brazil. Trans R Soc Trop Med Hyg 2006, 100:442-445.

17. Madeira MF, Schubach AO, Schubach TM, Pereira SA, Figueiredo FB, Baptista C, Leal CA, Melo CX, Confort EM, Marzochi MC: Post mortem parasitological evaluation of dogs seroreactive for Leishmania from Rio de Janeiro, Brazil. Vet Parasitol 2006, I 38 : 366-370.

18. Savani ES, Nunes VL, Galati EA, Castilho TM, Araujo FS, Ilha IM, Camargo MC, D'Auria SR, Floeter-Winter LM: Occurrence of co- infection by Leishmania (Leishmania) chagasi and Trypanosoma (Trypanozoon) evansi in a dog in the state of Mato Grosso do Sul, Brazil. Mem Inst Oswaldo Cruz 2005, 100:739-74I.

19. Madeira MF, Sousa MA, Barros JH, Figueiredo FB, Fagundes A, Schubach A, de Paula CC, Faissal BN, Fonseca TS, Thoma HK, Marzochi MC: Trypanosoma caninum n. sp. (Protozoa: Kinetoplastida) isolated from intact skin of a domestic dog (Canis familiaris) captured in Rio de Janeiro, Brazil. Parasitology, in press.

20. Vale AM, Fujiwara RT, da Silva Neto AF, Miret JA, Alvarez DC, da Silva JC, Campos-Neto A, Reed S, MayrinkW, Nascimento E: Identification of highly specific and cross-reactive antigens of Leishmania species by antibodies from Leishmania (Leishmania) chagasi naturally infected dogs. Zoonoses Public Health 2009, 56:4I-48.

21. Romero M, López M, Echeverry M, Rivas F: Leishmaniasis visceral canina: pruebas diagnósticas no identifican estados reales de la infección. Rev Salud Publica (Bogota) 2008, 10:290-298.

22. Killick-Kendrick R: Phlebotomine vectors of the leishmaniases: a review. Med Vet Entomol 1990, 4:I-24.

23. Young DG, Duncan MA: Guide to the identification and geographic distribution of Lutzomyia sand flies in Mexico, the West Indies, Central and South America (Diptera: Psychodidae). Mem Amer Entomol Inst 1994, 54: I-88I.

24. Lainson R, Rangel EF: Lutzomyia longipalpis and the ecoepidemiology of American visceral leishmaniasis, with particular reference to Brazil: a review. Mem Inst Oswaldo Cruz 2005, 100:8II-827.

25. de Pita-Pereira D, Alves CR, Souza MB, Brazil RP, Bertho AL, de Figueiredo Barbosa A, Britto CC: Identification of naturally infected Lutzomyia intermedia and Lutzomyia migonei with Leishmania (Viannia) braziliensis in Rio de Janeiro (Brazil) revealed by a PCR multiplex non-isotopic hybridisation assay. Trans R Soc Trop Med Hyg 2005, 99:905-913.

26. Jorquera A, González R, Marchán-Marcano E, Oviedo M, Matos M: Multiplex-PCR for detection of natural Leishmania infection in Lutzomyia spp. captured in an endemic region for cutaneous leishmaniasis in state of Sucre,Venezuela. Mem Inst Oswaldo Cruz 2005, 100:45-48.

27. Carvalho GM,Andrade Filho JD, Falcao AL, Rocha Lima AC, Gontijo CM: Naturally infected Lutzomyia sand flies in a Leishmaniaendemic area of Brazil. Vector Borne Zoonotic Dis. 2008, 8:407-4I4.

28. de Pita-Pereira D, Cardoso MA,Alves CR, Brazil RP, Britto C. Detection of natural infection in Lutzomyia cruzi and Lutzomyia forattinii (Diptera: Psychodidae: Phlebotominae) by Leishmania infantum chagasi in an endemic area of visceral leishmaniasis in Brazil using a PCR multiplex assay. Acta Trop 2008, 107:66-69.

29. Savani ES, Nunes VL, Galati EA, Castilho TM, Zampieri RA, FloeterWinter LM: The finding of Lutzomyia almerioi and Lutzomyia longipalpis naturally infected by Leishmania spp. in a cutaneous and canine visceral leishmaniases focus in Serra da Bodoquena, Brazil. Vet Parasitol 2009, 160:18-24.

30. Missawa NA, Lorosa ES, Dias ES: Preferência alimentar de Lutzomyia longipalpis (Lutz \& Neiva, 19/2) em área de transmissão de leishmaniose visceral em Mato Grosso. Rev Soc Bras Med Trop 2008, 41: 365-368.

31. Rotureau B, Ravel C, Aznar C, Carme B, Dedet JP: First report of Leishmania infantum in French Guiana: canine visceral leishmaniasis imported from the Old World. J Clin Microbiol 2006, 44: II 20-II 22

32. Carvalho MR, Lima BS, Marinho-Júnior JF, Silva FJ,Valença HF, Almeida FA, Silva AL, Brandão-Filho SP: Phlebotomine sandfly species from an American visceral leishmaniasis area in the Northern Rainforest region of Pernambuco State, Brazil. Cad Saude Publica 2007, 23:1227-I232.

33. Rosypal AC, Troy GC, Zajac AM, Frank G, Lindsay DS: Transplacental transmission of a North American isolate of Leishmania infantum in an experimentally infected beagle. J Parasitol 2005, 91 :970-972.

34. Freitas E, Melo MN, Costa-Val AP, Michalick MS: Transmission of Leishmania infantum via blood transfusion in dogs: potential for infection and importance of clinical factors. Vet Parasitol 2006, 137:159-167.

35. Silva FL, Oliveira RG, Silva TM, Xavier MN, Nascimento EF, Santos RL: Venereal transmission of canine visceral leishmaniasis. Vet Parasitol 2009, 160:55-59.

36. Sherlock I: Notas sôbre a transmissão da leishmaniose visceral no Brasil. Rev Bras Malariol D Trop 1964, 16:19-26. 
37. Coutinho MT, Bueno LL, Sterzik A, Fujiwara RT, Botelho JR, Maria M, Genaro O, Linardi PM: Participation of Rhipicephalus sanguineus (Acari: Ixodidae) in the epidemiology of canine visceral leishmaniasis. Vet Parasitol 2005, I 28:| 49-155.

38. Coutinho MT, Linardi PM: Can fleas from dogs infected with canine visceral leishmaniasis transfer the infection to other mammals? Vet Parasitol 2007, I 47:320-325.

39. Silva OA, Silva PB, Silva OV, Braga GM, Albuquerque Júnior A, Queiros Neto V, Rocha ME, Silva EF: La leishmaniose viscérale canine dans le Nord-Est du Brésil: aspects épidémiologiques. Bull Soc Pathol Exot 2007, 100:49-50.

40. Krauspenhar C, Beck C, Sperotto V, Silva AA, Bastos R, Rodrigues L: Leishmaniose visceral em um canino de Cruz Alta, Rio Grande do Sul, Brasil. Ciênc Rural 2007, 37:907-910.

4I. Salomon O, Sinagra A, Nevot M, Barberian G, Paulin P, Estevez J, Riarte A, Estevez J: First visceral leishmaniasis focus in Argentina. Mem Inst Oswaldo Cruz 2008, I03:109-III.

42. Margonari C, Freitas CR, Ribeiro RC, Moura AC, Timbó M, Gripp AH, Pessanha JE, Dias ES: Epidemiology of visceral leishmaniasis through spatial analysis, in Belo Horizonte municipality, state of Minas Gerais, Brazil. Mem Inst Oswaldo Cruz 2006, I0 I:31-38.

43. Balbino VQ, Coutinho-Abreu IV, Sonoda IV, Marques da Silva W, Marcondes CB: Phlebotomine sandflies (Diptera: Psychodidae) of the Atlantic forest in Recife, Pernambuco state, Brazil: the species coming to human bait, and their seasonal and monthly variations over a 2-year period. Ann Trop Med Parasitol 2005, 99:683-693.

44. Dantas-Torres F, Almeida FA, Brandão-Filho SP: Phlebotomine sandflies of an urban focus of visceral leishmaniosis, Pernambuco State. Rev Patol Trop 2006, 34:157-160.

45. Paranhos-Silva M, Freitas LA, Santos WC, Grimaldi G Júnior, Pontesde-Carvalho LC, Oliveira-dos-Santos AJ: A cross-sectional serodiagnostic survey of canine leishmaniasis due to Leishmania chagasi. Am J Trop Med Hyg 1996, 55:39-44.

46. França-Silva JC, da Costa RT, Siqueira AM, Machado-Coelho GL, da Costa CA, Mayrink W, Vieira EP, Costa JS, Genaro O, Nascimento E: Epidemiology of canine visceral leishmaniosis in the endemic area of Montes Claros Municipality, Minas Gerais State, Brazil. Vet Parasitol 2003, I I I:161-173.

47. Dantas-Torres F, Brito ME, Brandão-Filho SP: Seroepidemiological survey on canine leishmaniasis among dogs from an urban area of Brazil. Vet Parasitol 2006, I 40:54-60.

48. Rondon FC, Bevilaqua CM, Franke CR, Barros RS, Oliveira FR, Alcântara AC, Diniz AT: Cross-sectional serological study of canine Leishmania infection in Fortaleza, Ceará state, Brazil. Vet Parasitol 2008, I55:24-3I.

49. Padilla AM, Marco JD, Diosque P, Segura MA, Mora MC, Fernández MM, Malchiodi EL, Basombrío MA: Canine infection and the possible role of dogs in the transmission of American tegumentary leishmaniosis in Salta, Argentina. Vet Parasitol 2002, I I 0: I- I0.

50. Fernández J, Bello F, López MC, Moncada LI, Vargas JJ, Ayala MS, Nicholls RS, Lozano CA: Seroprevalencia de leishmaniosis visceral canina en la comuna 8 de Neiva y en cuatro municipios de Huila, Colombia. Biomedica 2006, 26: I2I-I30.

5I. Zerpa O, Ulrich M, Borges R, Rodríguez V, Centeno M, Negrón E, Belizario D, Convit J: Epidemiological aspects of human and canine visceral leishmaniasis in Venezuela. Rev Panam Salud Publica 2003, 13:239-2345.

52. Zanzarini PD, dos Santos DR, dos Santos AR, de Oliveira O, Poiani LP, Lonardoni MV,Teodoro U, Silveira TG: Leishmaniose tegumentar americana canina em municípios do norte do Estado do Paraná, Brasil. Cad Saude Publica 2005, 21:1957-1961.

53. Cortada VM, Doval ME, Souza Lima MA, Oshiro ET, Meneses CR, Abreu-Silva AL, Cupolilo E, Souza CS, Cardoso FO, Zaverucha do Valle T, Brazil RP, Calabrese KS, Gonçalves da Costa SC: Canine visceral leishmaniosis in Anastácio, Mato Grosso do Sul state, Brazil. Vet Res Commun 2004, 28:365-374.

54. Otranto D, Paradies P, de Caprariis D, Stanneck D, Testini G, Grimm F, Deplazes P, Capelli G: Toward diagnosing Leishmania infantum infection in asymptomatic dogs in endemic area. Clin Vaccine Immunol, in press.

55. Queiroz PV, Monteiro GR, Macedo VP, Rocha MA, Batista LM, Queiroz JW, Jerônimo SM, Ximenes MF: Canine visceral leishmaniasis in urban and rural areas of Northeast Brazil. Res Vet Sci 2009, 86: 267-273.
56. Costa-Val AP, Cavalcanti RR, de Figueiredo Gontijo N, Michalick MS, Alexander B,Williams P, Melo MN: Canine visceral leishmaniasis: relationships between clinical status, humoral immune response, haematology and Lutzomyia (Lutzomyia) longipalpis infectivity. Vet J 2007, 174:636-643.

57. Michalsky EM, Rocha MF, da Rocha Lima AC, França-Silva JC, Pires MQ, Oliveira FS, Pacheco RS, dos Santos SL, Barata RA, Romanha AJ, FortesDias CL, Dias ES: Infectivity of seropositive dogs, showing different clinical forms of leishmaniasis, to Lutzomyia longipalpis phlebotomine sand flies. Vet Parasitol 2007, 147:67-76.

58. Oliveira SS, Araújo TM: Avaliação das ações de controle da leishmaniose visceral (calazar) em uma área endêmica do estado da Bahia, Brasil (1995-2000). Cad Saúde Publica 19:168I1690.

59. Brandão-Filho SP, de Carvalho FG, de Brito ME, Almeida FA, Nascimento LA: American cutaneous leishmaniasis in Pernambuco, Brazil: eco-epidemiological aspects in 'Zona da Mata' region. Mem Inst Oswaldo Cruz 1994, 89:445-449.

60. Quinnell RJ, Kennedy LJ, Barnes A, Courtenay O, Dye C, Garcez LM, Shaw MA, Carter SD, Thomson W, Ollier WE: Susceptibility to visceral leishmaniasis in the domestic dog is associated with MHC class II polymorphism. Immunogenetics 2003, 55:23-28.

6I. David JR, Stamm LM, Bezerra HS, Souza RN, Killick-Kendrick R, Lima JW: Deltamethrin-impregnated dog collars have a potent anti-feeding and insecticidal effect on Lutzomyia longipalpis and Lutzomyia migonei. Mem Inst Oswaldo Cruz 200I, 96:839-847.

62. Reithinger R, Coleman PG,Alexander B,Vieira EP,Assis G, Davies CR: Are insecticide-impregnated dog collars a feasible alternative to dog culling as a strategy for controlling canine visceral leishmaniasis in Brazil? Int J Parasitol 2004, 34:55-62.

63. Otranto D, Paradies P, Lia RP, Latrofa MS, Testini G, Cantacessi C, Mencke N, Galli G, Capelli G, Stanneck D: Efficacy of a combination of $10 \%$ imidacloprid $/ 50 \%$ permethrin for the prevention of leishmaniasis in kenneled dogs in an endemic area. Vet Parasitol 2007, I 44:270-278.

64. Dantas-Torres F, Brandão-Filho SP: Visceral leishmaniasis in Brazil: revisiting paradigms of epidemiology and control. Rev Inst Med Trop Sao Paulo 2006, 48: I5I-I56.

65. Moreira ED Jr, Mendes de Souza VM, Sreenivasan M, Nascimento EG, Pontes de Carvalho L: Assessment of an optimized dog-culling program in the dynamics of canine Leishmania transmission. Vet Parasitol 2004, I 22:245-252.

66. Nunes CM, Lima VM, Paula HB, Perri SH, Andrade AM, Dias FE, Burattini MN: Dog culling and replacement in an area endemic for visceral leishmaniasis in Brazil. Vet Parasitol 2008, I 53:19-23.

67. Dantas-Torres F: Leishmune vaccine: the newest tool for prevention and control of canine visceral leishmaniosis and its potential as a transmission-blocking vaccine. Vet Parasitol 2006, I 1 I: I-8.

68. Fernandes AP, Costa MM, Coelho EA, Michalick MS, de Freitas E, Melo MN, Luiz Tafuri W, Resende Dde M, Hermont V, Abrantes Cde F, Gazzinelli RT: Protective immunity against challenge with Leishmania (Leishmania) chagasi in beagle dogs vaccinated with recombinant A2 protein. Vaccine. 2008, 26:5888-5895.

69. Vexenat JA, Barretto AC, Rosa AC: Infecção experimental de Lutzomyia whitmani em cães infectados com Leishmania braziliensis braziliensis. Mem Inst Oswaldo Cruz I986, 8I:I25-I 26.

70. Montoya-Lerma J, Cadena H, Oviedo M, Ready PD, Barazarte R, Travi BL, Lane RP: Comparative vectorial efficiency of Lutzomyia evansi and Lu. longipalpis for transmitting Leishmania chagasi. Acta Trop 2003, 85: 19-29.

7I. Hernández D, Rojas E, Scorza JV, Jorquera A: Infectividad del perro (Canis familiaris) para Lutzomyia youngi en Trujillo, Venezuela. Biomedica 2006, 26:242-248. 